Research.

\title{
MEASURING JOB PERFORMANCE OF THE ECONOMIC CREATIVE BUSINESS UPON WOMEN ENTERPRENEURS BASE (Case Study at Online Bunda Community Bogor Branch Using Balance Scorecard Approach)
}

\author{
Indar Khaerunnisa \\ STIE Binaniaga, Bogor, Indonesia
}

\begin{abstract}
Received: January 23, 2018; Accepted: April 9, 2018; Published: June 30, 2018
To cite this article: Indar Khaerunnisa, Measuring Job Performance of The Economic Creative Business upon Women Enterpreneurs Base (Case Study at Online Bunda Community Bogor Branch Using Balance Scorecard Approach), The Accounting Journal of BINANIAGA, Vol. 03, No. 01, June 2018, pp. 67 82.
\end{abstract}

Abstract. Balance scorecard has a privilege in terms of coverage measurement which is a fairly comprehensive because while taking into consideration the financial performance. Balance scorecard also consider the performance of non-financial performance, namely customer, internal business processes, and learning and growth. Referring to the problems encountered by Member of Bunda Online Community, this research examines: "Analysis of Company's Performance by Using Balanced Scorecard Approach (A Case Study Economic Creative Entrepreneur at Bunda Online Community)." Because until now Bunda Online Community has not been using the balanced scorecard to measure its job performance. The population of this study are permanent employees and 100 samples are taken as respondents. As for the customer respondents specified by 52 respondents total reseller and costumer in Bogor is only 52 reseller and costumer, however, it has obtained only 30 respondents who participated. Data used in this study are primary and secondary data. Based on the research and analysis, it can be concluded several things as the following: 1) The performance of the financial perspective on Economic Creative Entrepreneur in Bunda Online Community as a whole can be inferred or quite enough, in general financial ratios increased except ROA and TATO. 2) The performance of the customer perspective on Economic Creative Entrepreneur in Bunda Online Community as a whole can be inferred bad, because of poor customer satisfaction in the company's ability to maintain customer retention is also bad while in the company's ability to do customer acquisition is medium. 3) The performance of internal business process perspective on Economic Creative Entrepreneur in Bunda Online Community is enough, because innovation occurs only once during the past two years and there is not declining operating activities due to consistent time on the production clothing process. 4) The performance of learning and growth perspective in the Economic Creative Entrepreneur in Bunda Online Community may be concluded either on aspects of employee turnover or both criteria which decreasing employee productivity. Level of employee satisfaction is concluded less satisfied.

Keywords: balanced scorecard, financial performance, customer perspective, internal business processes, learning and growth perspective.

Indar Khaerunnisa: Measuring Job Performance of The Economic Creative Business upon Women Enterpreneurs Base (Case Study at Online Bunda Community Bogor Branch Using Balance Scorecard Approach) 


\section{INTRODUCTION}

\section{A. Background}

The Ministry of Cooperative Unit and UKM (small to middle business units) Anak Agung Gede Ngurah Puspoayoga said that National Entrepreneurship Movement (GKN) is the movement which is growing up from the grass root society that will become a strong foundation to evolve. Ratio of Indonesian Entrepreneurs in $2013 / 2104$ was still $1.67 \%$, but recently according to BPS data it is increasing to 3.1 $\%$. BPS data in 2016 has identified total of our population was 252 million people, total of permanent entrepreneurs non agriculture was 7.8 million people or $3.1 \%$. However, the Indonesian Entrepreneurs level has reached 2\% over the population which is the minimum requirement indicated as a prosperous society.

This kind of condition is getting along with fading away of the previous paradigm which declared that business world is dominated by man. In the last previous years, establishment and development of new business have been run and owned by women which is significantly evolving in developed countries, and followed by developing countries as well. Women entrepreneurs are the ones who have started a business and have been involving actively in managing their own business (Hendrayati, 2017).

In Indonesia, the development of business women has been evolving quite fast. The involvement of women in business worlds, specifically in micro and middle business units has quite significantly happened. Data of BPS year of 2015 has identified that $60 \%$ of 57.9 million entrepreneurs of micro and medium business units (UMKM) are women.

The roles of women entrepreneurs are very important to increase a district economics. In economical activity, women enterpreneurs are not only strengthening the family economical power, but also can hire a lot of employees, reduce jobless people and decrease poverty people, so that, they can make a continuous economics development come true (Hendrayati, 2017).

There are some differences between businessman and businesswomen accordingly. It is quite interesting that businesswomen roles are more complex than businessman. Business women have applied an autonomous entrepreneurship to integrate the family's goal, personal interest which is getting along with the objectives of their business. However, businessmen are only focusing to the job oriented referred to the market opportunity. They do not integrate their personal life with their business as women do.

Though the stereotype of the community in Indonesia that women are depending on their husband to raise their family, as a matter of fact, they have their own autonomy on their business. It means that they have got their husband and family's support to run their business, since they can provide additional income, develop their hobby, creativity as well as having socialized atmosphere.

Business which has been performed by women needs a measurement to measure the job performance of the company. This kind of measurement is important to evaluate their business refers to their company to set up their future. Various information have been gathered in order to control and to be responsible for their business. It should have to done in order to achieve an efficient and effective business process of the company. The company's job performance has been achieved from two resources which is the financial information and non-financial information. Financial information has identified budgeting to control cost and expenses. Non-financial information has identified key-factors to determine a strategy chosen and to execute the objectives stated.

Both information above can be analyzed by using several model of the company job performance measurement, one of them is balance scorecard. Balance

Indar Khaerunnisa: Measuring Job Performance of The Economic Creative Business upon Women Enterpreneurs Base (Case Study at Online Bunda Community Bogor Branch Using 
Scorecard is the management tool to replace the previous model of scorecard concept which had been chasing only a short term of profitability. However, Balance scorecard is a comprehensive framework to understand the company vision and mission as well as its strategy within an integrated job performance measurement which is well structured refers to four perspectives; financial, customer, internal business process and learning and growing (Hardiyanto, et.al 2005)

Community of Bunda Online is a community which has been started by some women entrepreneurs in Bogor who have joined together and created an online chatting group named KBO. This community was established beginning 2016 and was officially legitimated by Mrs. Mayor of Bogor. This community has been teaching a proper marketing internet education and supporting to create a good environment of online business in Bogor. This community is having varied programs to be done in order to develop women as new economic resources without leaving her duty as wife and mother of her children. From time to time, the members of this community have been increasing, and recently it has got 150 creative women entrepreneurs which is consisting of food and non food entrepreneurs who have been receiving net earnings about Rp 20.000.000.- to Rp 100,000,000.- per year. However, they have never been doing any job performance measurement. It is expected that by having job performance measurement, they can identify unexpected problems to be dealt with or decreasing of job performance refers to non financial perspective accordingly. In order to solve the problems, the entrepreneurs are expected to use balance scorecard method to measure their business job performance. By applying such performance measurement, they could recognize how effective the implementation of the strategy has been applied in the organization and they could evaluate the achievement of organization management executing its activity. Nevertheless it could be applied as the basic of system designed in the organization to achieve the expected goal (Mulyadi and Setyawan, 2002).

Balance scorecard is having a specific comprehensive measurement since it is not only considering the financial performance, but also considering non-financial performance which is customers, internal business process, learning and growing. Besides that, balance scorecard is not only measuring end results, but also measuring the activities to achieve the end result. Measuring the related driver is consistent and is getting along with Porter which is in Kaplan and Norton idea (1996) who defined that "only by moving to the level of underlying drivers can the true sources of competitive advantage be identified".

Based on the background of the problem above, it is very interesting to study furthermore regarding the achievement of company's job performance by using balance scorecard concept. Anticipating the problems that will probably be encountered by the members of Bunda Online Community, the writer is interested in doing such a research with the following theme: "An Analysis of the Job Performance Measurement of Economic Creative Business upon Women Entrepreneurs Bases by applying Balance Scorecard Approach".

\section{B. Problems Formulation}

Job Performance Measurement concept that is only focusing to financial aspect has been left gradually as it is only dealing with a short term of profitability goals. Balance scorecard is a new paradigm in a recent development of accountancy management which is expected to be applied by the entrepreneurs who are facing more complex competitive business. Besides that, it can encourage more information needed by the management to figure out the operation achievement and failure done by the company, as well as to get rid of traditional performance measurement which is orientated only on a short-term financial achievement. Based on the background above, the problem which is going to be studied is "How has job performance of creative economic business women based on balance scorecard concept covering

Indar Khaerunnisa: Measuring Job Performance of The Economic Creative Business upon Women Enterpreneurs Base (Case Study at Online Bunda Community Bogor Branch Using Balance Scorecard Approach) 
finance perspective, customer perspective, internal business perspective and learnt and growth perspective been working?"

\section{Objective of The Research}

Be consistent with the problem formulated above, the objective of the research achievement expected is to find out the job performance of creative economic business of women entrepreneurs based on balance scorecard concept covering financial perspective, customer perspective, internal business perspective and learnt and growth perspective.

\section{Benefit of The Research}

This research is expected to provide the following benefits:

1. For the purpose of academic institution, this research is expected to give additional empirical evidence regarding the job performance of women entrepreneurs who is running creative economic which has been measured by using balance scorecard concept.

2. For the purpose of women entrepreneurs of creative economic, this research is expected to provide an input of comprehensive job performance evaluation system using balance scorecard which is able to evaluate its job performance evaluation more comprehensive.

3. For the purpose of researcher, it could give better understanding about the job performance evaluation of the entrepreneurs using balance scorecard.

4. For the purpose of the readers, it could be as additional information and scientific issue either for the readers in general or for the students specifically.

\section{LITERATURE REVIEW}

\section{A. Job Performance of The Company}

\section{Definition of Company's Job Performance}

Job Performance of a company is a real actual information of company totally during a certain period which is the result of its achievement influenced by the operational activities of the company which has been using its available resources (Helfert, 1996 in Ceacilia Srimindarti, Economic Focus. 2004:53).

\section{Definition of Job Performance Measurement and Job Performance} Evaluation

According to some experts, the differences of definition job performance measurement and job performance evaluation, as follows:

a. Job Performance Measurement

According to Anderson and Clancy (Sony Yuwono, et. Al., 2002:21), defined job performance measurement is as follows:

"Feedback from the accountant to management that provides information about how well the action represent the plants; it also identifies where manager may need to make corrections or adjustment in future planning and controlling activities".

b. Job Performance Evaluation

According to Mulyadi and Johny Setyawan (2002: 227), have defined that job performance evaluation is periodical identification of effective operational organization, parts of organization, and employees based on the goals, standard, and criteria has been stated before. 


\section{Controlling and Job Performance}

Controlling is a process directing a group of variables which is covering human, things, situation and organization to achieve the goals and objectives stated before. However, job performance is a complete situation of a company for a certain period, is the result or achievement influenced by the operational activities of company which has been using the benefit of resources owned.

\section{Objectives of Job Performance Measurement}

Referring to Vincent Gaspersz (2005:68), objective of job performance measurement is to produce the data which furthermore if the data is analyzed accurately, it will provide an accurate information for the user of related data. Based on the objectives of job performance measurement, it is a job performance measurement method which is in line with the company's goal congruence.

\section{Objectives of Job Performance Evaluation}

Main objective of job performance evaluation (Mulyadi and Johny Setyawan, 2002:227) is to motivate people to reach the company's goal and to respect the behavioral standard which is management policy or formal planning designed in the organization's budget that has been issued before in order to produce the actions and the results required by organization.

\section{Benefit of Job Performance Measurement}

Benefit of good job performance measurement system as the following: (1) Exploring the job performance upon the customers' expectation which can bring the company closer to the customers and make all the people in organization be involved in making the customer satisfied. (2) Motivating employees to perform their service as part of interrelationship between customers and internal suppliers. (3) Identifying some expenses to support the efforts of waste reduction. (4) Determining strategic goal of the company to be more clear and actual to speed up the organization learning process. (5) Building up consensus to make a change by giving rewards upon the expected behavior.

\section{Benefit of Job Performance Evaluation}

Benefit of job performance evaluation for the company's management (Mulyadi, 2001: 416) is as follows: (1) Managing operational organization effectively and efficiently thru motivating the employees more maximum. (2) Assisting decision making related to employees, such as: promotion, transfer and lay-off. (3) Identifying training and development needed by the employees and to provide selection criteria and evaluation of the training program for the employees. (4) Providing feed-back for the employees regarding how their superior has evaluated their job performance. (5) Providing basic standard of reward distribution. (6) Rewarding is classified into two (2) groups which is intrinsic and extrinsic reward.

\section{Job Performance Size}

There are three size of measurement that can be used to evaluate it quantitatively (Mulyadi, 2001: 434), as follows: (1) Single Criteria Size. (2) Various Criteria Size. (3) Combined Criteria Size.

\section{B. Measuring Company Job Performance Using Balance Scorecard Approach.}

\section{Definition of Balance Scorecard}

Balance scorecard is a job performance measurement of a company which is measuring job performance of a company overall either finance of non finance by considering four aspects related to the company which is as follows; financial 
aspect, customer aspect, internal business process aspect, and learnt and growth aspect.

\section{Developing Balance Scorecard}

Referring to Rohm (2003) in Imelda R.H.N (JAK. 2004), before implementing balance scorecard, an organization should have to develop or to design a balance scorecard. There are six level developing BSC, as follows:

a. Evaluating Organization foundation

First step of an organization to evaluate the organization foundation is by establishing a team that will be designing and building up balance scorecard.

b. Developing Business Strategy

This strategy is obtained from the mission and result of foundation evaluation. Strategy has declared what kind of action should have to be done by organization to achieve the organization's mission which is in compliance with the strength and weakness of organization.

c. Determining the Organization Goals

Organization goals have identified what kind of action should have to be done to execute its strategy. It has described the activities that should have to be done upon the strategy and the time required to achieve the achievement required.

d. Designing Strategic Map of Organization Business Strategic.

Many organizations are having some units which are having its individual strategy and objectives. In order to run it effectively, the strategy and objectives should have to be connected and joined together. Joining and connecting the related strategies and objectives required is a strategic map.

e. Measuring Job Performance

Measuring job performance is to supervise and to measure the achievement of strategic objectives designed. Measuring job performance aims to improve the organization to be better.

f. Designing Initiative

Initiative is the programs to be executed to meet one or some strategic objectives. Before stating an initiative, it should have defined a target. Target is a job performance achievement required.

\section{Balance Scorecard as Strategic Management System.}

Kaplan and Norton (1996: 9) defined that BSC is a system of tactical or operational measurement. Innovative companies are applying balance scorecard as strategic management system to manage a long-term strategy. Companies have been focusing to balance scorecard measurement to produce various important management processes, as the following:

a. Clarifying and translating a vision and strategy.

Balance scorecard process has been started by senior executive management team altogether to translate the strategic business unit into various specific strategic goals. The process of balance scorecard development has been describing strategic goal and identifying some important driving factors of strategic goals.

b. Communicating and connecting various objectives and strategic size.

Objectives and size of strategic BSC should have to be communicated to all over the organization by giving information to all employees about various important strategic company objectives to be achieved.

c. Planning, determining goals, and getting along with various strategic initiatives.

Indar Khaerunnisa: Measuring Job Performance of The Economic Creative Business upon Women Enterpreneurs Base (Case Study at Online Bunda Community Bogor Branch Using 
Planning and management process determining some goals to make the company possible measuring long-term result expected to be achieved, identifying mechanism and providing resources to reach the achievement, and defining short-term pillars refers to financial and non-financial scorecard measurement.

d. Increasing the feed-back and strategic learning.

Feed-back process is the process defining vision and strategy, communicating and connecting vision and strategy to all members of organization, as well as getting along with actions and initiative of the company to reach long term strategic objectives.

\section{Implementation Concept of Balance Scorecard Perspectives}

a. Financial Perspective

In order to build-up a balance scorecard, business units should have to be in line with the financial objective related to the strategies of a company. Balance scorecard has applied the financial perspective since financial performance evaluation is the summary of economic consequences done by company.

b. Customers Perspective

A product or service is considered having the value for the customers if its benefit accepted by the customers are relatively higher than the effort of customers to get the product or the service. A product or service will be more valuable if its benefit is close to or more than customer's expectation.

c. Internal Business Process Perspective

Each company is having a chain of process to create unique value for the customers and to receive good financial result. In general, Kaplan and Norton (1996: 83) devided into three basic principles; innovation, operation and after sales service.

d. Learnt and Growth Perspective

The fourth perspective of BSC aims to develop the objectives and size supporting the learning and growing of the company. Objectives stated on the financial perspective, customer perspective, internal business process perspective are identifying what the company should have to gain in order to achieve the extraordinary job performance.

\section{Balance Scorecard Superiority}

Superiority of balance scorecard approach in the system of strategic planning is the ability to produce characteristic of strategic planning (Mulyadi, 2001: 18) which is comprehensive, coherent and measurable.

\section{Opinion Framework}

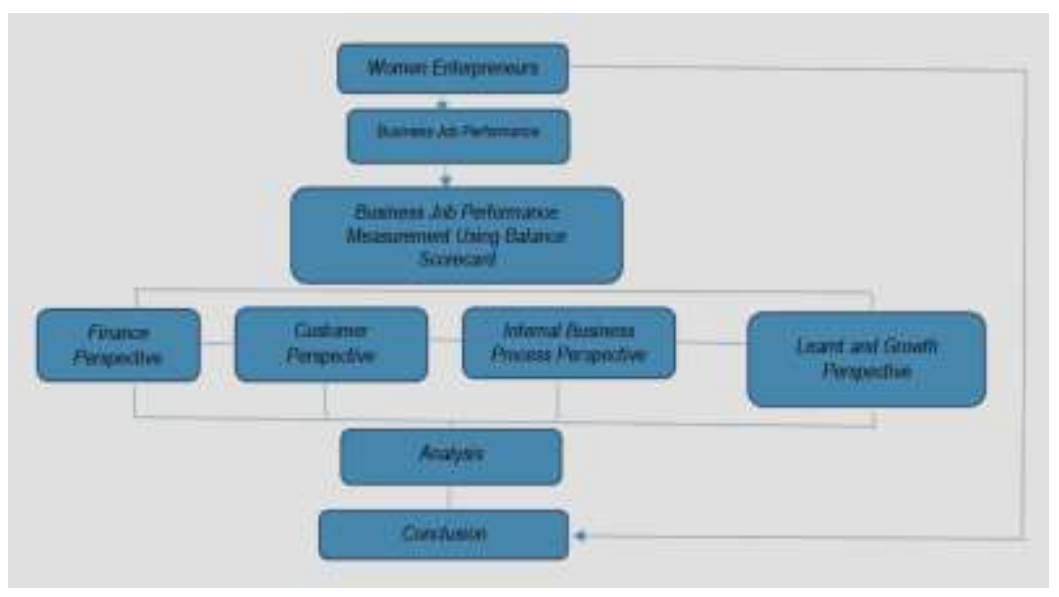

Indar Khaerunnisa: Measuring Job Performance of The Economic Creative Business upon Women Enterpreneurs Base (Case Study at Online Bunda Community Bogor Branch Using Balance Scorecard Approach) 


\section{Correlation Inter Perspectives}

\section{Inter-perspective correlation}

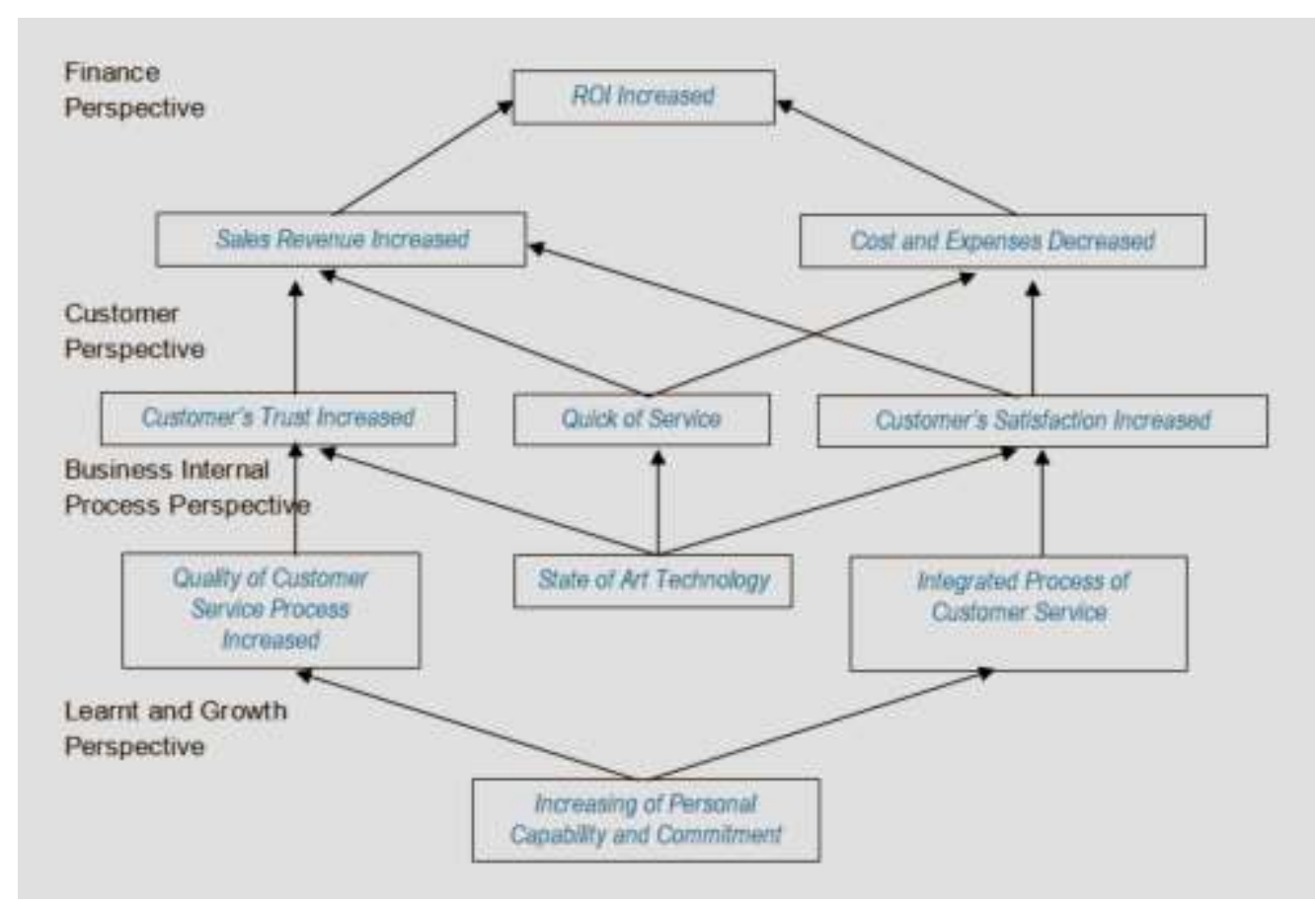

Source : Mulyadi and Johny Setyawan, 2002. System of Planning and Controlling Management.

\section{RESEARCH METHOD}

\section{A. Population and Sample}

Population of this research are 25 women in Bogor who are having creative business in clothing production sector and have joined Bunda Online Community, and they have 100 employees overall who are the respondents. However, customer respondents have been decided only 52 respondents since the customers and permanent resellers who are in compliance with the requirements is only 52 persons. Nevertheless, there are only 30 people of customer and reseller who have been participating.

\section{B. Type of The Data and Technique of Data Collectopn}

\section{Type of The Data}

Data that have been used in this research are Primary data and Secondary data.

\section{a. Primary Data}

Primary data that have been used in this research are opinion of the subject which is directly received from the respondents either KBO members or consumers. Data of employee satisfaction are received from the employees of each company. However, data of customers' satisfaction are received from the customers and resellers represented by 30 customers and resellers. Nevertheless data of employees who have been selected are only 100 employees from all the total employees. 


\section{b. Secondary Data}

Secondary data are the data received from data published ( $\mathrm{J}$. Supranto, 1993: 8). Generally, secondary data are evidence, records, or historical reports which have been filed in the archiving reported.

This research has used secondary data as follows:

1) Financial reports which is Balance Sheet and Profit and Loss report for the period of $2016-2017$.

2) Total of the employees years of 2016, 2017

\section{Technique of Data Collection}

Method that is being used is questionnaires which is a bundle of questions that has been formulated in written with the purpose of having the opinion of respondents, and the answers have been provided by using the similarity alternative to choose (Sekaran: 2000). But, technique of secondary data collection is using library and documentation review.

\section{Data Measurement}

\section{Finance Perspective}

There are five ratios to be measured in finance perspective:

a. Gross Profit Margin Gross profit margin has figured out the profit received from sales.

b. Operational profit margin Operational profit margin has figured out the operational profit received from sales.

c. ROA

To calculate returned of the assets belong to the company.

d. Current Ratio To find out the value of current assets compared with current liabilities used.

e. TATO

To find out the total value of sales compared with total assets.

\section{Customer Perspective}

Customer perspective is calculated by using the following calculation:

a. Customer Retention In order to find out how many customers have been switched compared to the total of customers owned by the company.

b. Customer acquisition In order to find out how many new customers have been caught compared to the total of customers.

\section{Internal Business Process Perspective}

\section{culation}

Refers to Internal business process perspective, it will use the following

a. Innovation Process

Calculating the percentage of new product sales by comparing the total of new product with the previous one.

b. Operational Process

Measuring the operational activities based on time, quality and cost.

\section{Learning and Growing Perspective}

\section{calculation:}

Learning and growing perspective will be applying the following

a. Level of Employees Turn-over

Employee turnover is good when there is a decreasing of employees turnover during the observation period, and it is quite good if it is fluctuated, however, it is bad if turnover of the employees has been increasing. 
b. Level of employees' productivity

Criteria of learnt and growth perspective is indicated by the productivity of employees is developing a long-term of job performance. (Kaplan: 2001).

c. Level of Employees satisfaction

Employees are considered satisfied if majority of employees has given the answer of very satisfied or satisfied, however, it is quite satisfied if most of them has replied neutral, nevertheless it is not satisfied if most of them has replied not satisfied and the most unsatisfied.

\section{Validity and Reliability Test}

\section{Validity Test}

In order to test the validity, the correlation of each questions refers to total score can be calculated by using Pearson Products Moment correlation technique.

\section{Reliability Test}

Referring to Imam Ghozali (2001), reliability test is to measure the questionnaire as the indicator of inter variables (construct). The measurement is done only once and then the results are being compared with the questions or measured the correlation of the answers accordingly. A construct / variable is considered reliable if it has got the value of Cornbach alpha of 0.6 (Imam Ghozali, 2001).

\section{E. Analysis Equipment}

\section{Qualitative Analysis}

Qualitative analysis has been done using data disclosure and data interpretation and the result of the research using verbal language based on the standard or the comparison result of each treatment which is going be used as the standard of decision making.

\section{Quantitative Analysis}

This research has applied quantitative analysis to evaluate financial perspective, customer perspective, internal business process perspective, and learnt and growth perspective.

Steps to be done to execute the evaluation of job performance of creative economic business entrepreneurs are as follows:

a. Tabulating the result of questionnaires distributed to the respondents into numerical result using Likert scale.

b. Comparing the condition of a company with balanced criteria at each perspective required in balance scorecard to find out the possibility of implementing it on the research object by considering any improvement efforts that should have to prepared by object of the research thru the target which has been defined by each creative economic business entrepreneurs.

c. .Providing the implementation of the result of job performance measurement. Measuring job performance has been done by defining a range of the value to identify company job performance whether it is on the bad level, medium and good one.

d. Evaluating the measurement system using balance scorecard approach which has been interpreting the result of job performance measurement upon the evaluation of measurement system determined by the creative economic business entrepreneurs.

Indar Khaerunnisa: Measuring Job Performance of The Economic Creative Business upon Women Enterpreneurs Base (Case Study at Online Bunda Community Bogor Branch Using 


\section{RESULT AND DESCRIPTION}

\section{A. Company General Information}

\section{Summary of Company Development History}

Bunda Online Community or KBO is a community of women in Bogor who are having a business either off-line or online. This community has had various programs that will be done due to the purpose of women development as new economic resources since they do not need to put aside of their tasks as wives and mothers of their children. It has a tag-line "Going forward and being success all together". Bunda Online Community established on 30 January 2016 and officially legitimated by Mrs.Mayor of Bogor which has become the place of 150 members who are creative economic business women in Bogor. They are running their business in various sectors of products and services locally and overseas and their sales have been achieving hundreds million rupiah.

\section{Financial Perspective Analysis}

Indicators of financial perspective in balance scorecard are financial ratios such as gross profit margin, operational profit margin, ROE, ROI, current ratio, total of assets turnover, ratio of total capital against total assets. Result of the financial perspective performance calculation is as the following;

Table 1. Financial Perspective Performance

\begin{tabular}{|l|c|c|c|l|}
\hline \multicolumn{1}{|c|}{ Measurement } & $\mathbf{2 0 1 6}$ & $\mathbf{2 0 1 7}$ & $\begin{array}{c}\text { On } \\
\text { Average }\end{array}$ & Criteria \\
\hline Gross profit margin & 0.75 & 0,82 & 0,785 & Good \\
\hline Operational Profit margin & 0,217 & 0,165 & 0,191 & Good \\
\hline ROA & 0,047 & 0,020 & 0,0335 & Bad \\
\hline CR & 32.721 & 12.138 & $22.429,5$ & Good \\
\hline TATO & 0,441 & 0,432 & 0,421 & Bad \\
\hline
\end{tabular}

Source : primary data processed (2018)

\section{Customer Perspective Analysis}

a. Consumer retention and acquisition

Based on the calculation of customer perspective job performance, the following results are as follows:

Table 2. Customer Perspective Job Performance

\begin{tabular}{|l|c|c|c|c|}
\hline \multicolumn{1}{|c|}{ Measurement } & $\mathbf{2 0 1 6}$ & $\mathbf{2 0 1 7}$ & Average & Criteria \\
\hline Consumer Retention Criteria & 0 & 0,043 & 0,0215 & Bad \\
\hline Consumer Acquisition & 0,098 & 0,082 & 0,09 & Medium \\
\hline
\end{tabular}

Source : Primary data processed (2018)

b. Customers Satisfaction

The price of clothes produced by Bunda Online Community is in compliance with the quality and it makes me satisfy $\left(\mathrm{X}_{1}\right)$

Table 3. Feedback of price compliance with quality

\begin{tabular}{|ll|c|c|}
\hline \multicolumn{1}{|c|}{ Reply } & Total & Percentage \\
\hline 1 & The most dissatisfied & 5 & 16,7 \\
\hline 2 & Dissatisfied & 15 & 50 \\
\hline 3 Quite satisfied & 4 & 13,3 \\
\hline
\end{tabular}

Indar Khaerunnisa: Measuring Job Performance of The Economic Creative Business upon Women Enterpreneurs Base (Case Study at Online Bunda Community Bogor Branch Using Balance Scorecard Approach) 


\begin{tabular}{|c|c|c|}
\hline Reply & Total & Percentage \\
\hline 4 Satisfied & 6 & 20 \\
\hline 5 The most satisfied & 0 & 0 \\
\hline Total & 30 & 100 \\
\hline
\end{tabular}

Source : Primary data processed (2018)

Table 4. Quality and tidiness of the clothes

\begin{tabular}{|l|c|c|}
\hline \multicolumn{1}{|c|}{ Replye } & Total & Percentage \\
\hline 1. The most dissatisfied & 3 & 10 \\
\hline 2. Dissatisfied & 4 & 13,3 \\
\hline 3. Quite satisfied & 0 & 0 \\
\hline 4. Satisfied & 18 & 60 \\
\hline 5. The most satisfied & 5 & 16,7 \\
\hline \multicolumn{1}{|c|}{ Total } & 30 & 100 \\
\hline
\end{tabular}

Source : Primary data processed (2018)

Table 5. Compliance of the model with the recent trending

\begin{tabular}{|l|c|c|}
\hline \multicolumn{1}{|c|}{ Reply } & Total & Percentage \\
\hline 1. The most dissatisfied & 4 & 13,3 \\
\hline 2. Dissatisfied & 2 & 6,7 \\
\hline 3. Quite satisfied & 0 & 0 \\
\hline 4. Satisfied & 21 & 70 \\
\hline 5. The most satisfied & 3 & 10 \\
\hline \multicolumn{1}{|c|}{ Total } & 30 & 100 \\
\hline
\end{tabular}

Source : Primary data processed (2018)

Table 6. Overall Satisfaction result

\begin{tabular}{|l|c|c|}
\hline \multicolumn{1}{|c|}{ Reply } & Total & Percentage \\
\hline 1. The most dissatisfied & 3 & 10 \\
\hline 2. Dissatisfied & 4 & 13,3 \\
\hline 3. Quite satisfied & 0 & 0 \\
\hline 4. Satisfied & 18 & 60 \\
\hline 5. The most satisfied & 5 & 16,7 \\
\hline \multicolumn{1}{|c|}{ Total } & 30 & 100 \\
\hline
\end{tabular}

Source : Primary data processed (2018)

\section{Analysis of Internal Business Process Perspective}

Table 7. Jov Performance of Internal Business Process Perspective

\begin{tabular}{|c|c|c|c|c|}
\hline Measurment & $\mathbf{2 0 1 6}$ & $\mathbf{2 0 1 7}$ & Average & Criteria \\
\hline Innovation & 0 & 1 & 1 & Medium \\
\hline
\end{tabular}

Source : Primary data processed (2018)

Indar Khaerunnisa: Measuring Job Performance of The Economic Creative Business upon Women Enterpreneurs Base (Case Study at Online Bunda Community Bogor Branch Using 
Table 8. Calculation of Operational Activities of Clothing Production

\begin{tabular}{|l|c|c|c|c|}
\hline $\begin{array}{c}\text { Measurement } \\
\text { Cycle } \\
\text { Effectiveness }\end{array}$ & $\mathbf{2 0 1 6}$ & $\mathbf{2 0 1 7}$ & Average & Criteria \\
\hline MCE Design & 0.117 & 0.147 & 0.132 & Medium \\
\hline MCE Patterning & 0.441 & 0.441 & 0.441 & Medium \\
\hline MCE Cutting & 0.176 & 0.176 & 0.176 & Medium \\
\hline MCE Finishing & 0.088 & 0.088 & 0.088 & Medium \\
\hline
\end{tabular}

Source : Primary data processed (2018)

For the last two years MCE design has been increasing since the employees at design department who resigned have been replaced by the new ones. But, MCE patterning, cutting and finishing are constant.

\section{B. Analysis of Learnt and Growth Perspective}

In one industry, there is a tendency of competitive increasing, so that, the company should have to keep the potential employees and to increase their productivity. The calculation of learnt and growth perspective is attached, however the result is as the following:

1. Based on the calculation of employees' turnover criteria, it has indicated that employees' turnover is within good criteria, but productivity ratio is within bad criteria.

2. Employees' productivity has been indicated by the comparison between the operational profit achieved by the company with the total of employees at the related year. And the result of employees' productivity has been decreasing during 2016 and 2017 which is 1.183 .605 in 2016 decreased to 738.57 in 2017.

3. Calculation of respondents' feedback upon job satisfaction aspect has indicated mostly within satisfied category $(57 \%)$. It has explained that in general the employees are satisfied with their title in the company.

4. Majority of respondents have replied satisfied upon their salary, however $34 \%$ has replied dissatisfied. It has figured out that the employees are not satisfied with the salary given. It is normal since in general the employees have always been dissatisfied with the salary received.

5. Referred to the questions about the satisfaction of promotion policy, respondents feed-back mostly are within the criteria of satisfied which is $45 \%$, however $50 \%$ (the respondents who have replied within the most dissatisfied, dissatisfied and neutral) indicating that employees are not quite sure whether or not they are satisfied with the existing promotion policy.

\section{Description}

From the financial perspective, it has explained that gross profit margin, operational profit margin and current ratio are within in good criteria, but ROA and TATO are within bad criteria. Variable of gross profit margin has not only been more than $6 \%$ during two years of the observation but it also has been increasing. However, the variable of operational profit margin has also always been more than $6 \%$ for the last two years. Nevertheless, decreasing of operational profit margin in 2017 has been happened due to sales increasing at the same year, but it has not been followed by the increasing of operational profit. It has happened due to the inefficiency result which is the increasing of operational cost. Current ratio variable (CR) has always been more than $200 \%$ for the last three years, CR value $(3.271 \%$ and $1.213 \%$ ), however CR value which is too big is advised to be decreased because a short-term liquidity of big value is not good, especially when inventory

Indar Khaerunnisa: Measuring Job Performance of The Economic Creative Business upon Women Enterpreneurs Base (Case Study at Online Bunda Community Bogor Branch Using Balance Scorecard Approach) 
stock value is quite huge. ROA variable is within bad criteria and for three years it has been less than $7 \%$ which is, each (4.7\% and $2 \%)$, though gross profit margin and operational cost are relatively huge, this low ROA value has happened due to big amount of the value of company assets. At customer perspective, it has indicated that retention variable is within bad criteria, since for two years the total of customers who has cut off the relationship with the companies has been increasing. In 2016, there was not any consumer who had cut off the relationship with the company, however in 2017 there was a huge reseller who cut off the relationship with the company and the year after two more huge resellers had cut of their business relationship with the company. Nevertheless, from the acquisition point of view of company, it has gained new customers more than the total of retailing agent who has cut off the relationship with the company. On the internal business process perspective, innovation had happened only in 2017, the company was advised to make innovation more active. However MCE process is within medium criteria as the MCE process has been fluctuating but it has not had any constant improvement. If it is possible selling non productive assets and the revenue could allocate to purchase new equipments and machines to improve the production process.

However, on learning and growth perspective, job performance of employees' turnover has been within good criteria due to employees' turn over has been decreasing during the observation period. Nevertheless, productivity of employees has decreased due to increasing of the total of employees that have not been in accordance with the increasing of earnings records. Satisfied variable has identified that employees are not quite satisfied with all aspects of job, salary, promotion policy, superior support and peers teamwork. Referred to comprehensive analysis, it could be concluded that bad job performance of operational profit has happened because of: first, low level of employees' satisfaction has been affecting low productivity of the employees. Decreasing productivity of the employees has caused high cost to be spent by the company and on the other hand employees cannot give maximum contribution to the financial of the company. Retention and acquisition of the consumers are in bad criteria and it has implicated less products received by members of KBO. So far the companies have ignored domestic market since it is considered giving less profit margin than the products exported.

In order to make the vision of "commitment to the consumers" come true, improving customer service is required as maximum as possible. Improving customer service is expected would able to decrease customer turnover up to zero point for the next coming years, so that total of consumers will be increasing quantitatively. Increasing of consumers is expected would be increasing the total of sales of domestic market and would be implicating to the increasing of financial performance obviously.

\section{CONCLUSION AND SUGGESTION}

\section{A. Conclusion} follows:

Based on the result and analysis of this research, it could be concluded as

\section{Financial Perspective}

Job Performance of financial perspective of the members of KBO clothing section overall can be concluded or evaluated at medium one, since in general financial ratios have been increasing except ROA and TATO. Gross profit margin had increased for 2 years in 2016 and 2017. ROA had decreased in 2017. Variable current ratio had decreased for two years. But TATO had been decreasing continuously during the observation period. 
2. Customer Perspective.

Job Performance of customer perspective of KBO community members at clothing section is not good, since the customer satisfaction is not quite satisfied at the dimension of price and quality compliance, company ability to keep the consumers is not good, however acquisition of customers is quite good. Consumers' retention has been increasing during the observation period of time, however, the acquisition of customers which has been started at $9.8 \%$ point has been decreasing for the following year.

3. Internal Business Process Perspective

Job Performance of Internal Business Process of KBO has been quite good since its innovation has happened only twice within two years, however there has not been any decreasing of operational activities happened consistently in the production process.

4. Learning and Growth Perspective

Job Performance of learning and growth perspective of KBO can be determined good refers to employees turnover is good, but the employees productivity has decreased. Employees' satisfaction level is quite good due to the employees who are dissatisfied.

\section{B. Limitation}

The limitation of this research has happened due to the researcher could not find out the right time to meet the consumers, as the time given is only short one and the feed-backs from the customers as housewives have taken quite long, they are the resellers who are having absolute activity time at home that cannot be disturbed. Nevertheless, by having persistence we have met them at last.

\section{Suggestions}

1. Financial perspective of gross profit margin should have to be maintained, since it has tended to increasing during the period of observation. However operational profit margin should have to be improved since it has not been stable during the period of observation. Nevertheless, current ratio and ROA should have to be improved since it has decreased accordingly, as well as assets turnover ratio needs to be kept as it is. But current ratio variable has been increasing and is liquid during the period of observation, so that, it has to be maintained.

2. Besides of increasing total of new resellers, the company is advised to keep the existing resellers. It has to done to avoid any quantity of resellers decreased which could affect negative sales.

3. The company is advised to execute product innovation by creating new product to meet customers' requirement. Company is also advised to improve the production processing time to be more efficient.

4. Learning and Growth Perspective especially refers to employees satisfaction should have to be paid more attention which is job placement, job placement system, superiors attitude, organization policy and job career path opportunity, so that the employees satisfaction could be increased.

\section{REFERENCES}

As'ad, Moh., 1995, Psikologi industri, Penerbit Liberty, Yogyakarta

Azwar, Saifudin, 1997, Penyusunan skala psikologi, Yogyakarta, Pustaka Pelajar.

Indar Khaerunnisa: Measuring Job Performance of The Economic Creative Business upon Women Enterpreneurs Base (Case Study at Online Bunda Community Bogor Branch Using Balance Scorecard Approach) 
Citptani, Monika Kussetya, 2000, Balanced scorecard sebagai pengukuran kinerja masa depan: Suatu Pengantar, Jurnal Akuntansi dan Keuangan Vol. 2, No. 1, Mei 2000.

Gaspersz, Vincent, 2001, Production planning and inventory control, Gramedia Pustaka Utama, Jakarta

Hansen and Mowen, 2004 Akuntansi manajemen, penerjemah oleh Ancella A, Hermawan, Jakarta: Erlangga

Hartanto, Lukas, 2008, Mengukur kinerja perusahaan dan mencari akar permasalahan dengan menggunakan metode balanced scorecard: studi kasus pada perusahaan bumbu masa kepala sapi Semarang, Skripsi Unika Tidak dipublikasikan.

Imam Ghozali, 2001, Aplikasi analisis multivariate dengan program SPSS, Badan penerbit Universitas Diponegoro, Semarang

Indra Gunawan, 2008. Implementasi balanced scorecard with six sigma untuk mengukur kinerja berdasarkan prinsip good governance di kantor pelayanan pajak modern: studi kasus KPP PMA satu. Tesis Universitas Indonesi.http://www.digilib.ui.ac.id//opac/themes/libri2/detail.jsp?id=9052 6\&lokasi=local

Kaplan, Robert S., Norton, David P., (2000), Strategy maps (converting intangible assets into tangible outcomes), Harvard Business School Press

Moh. Nasir. Ph.D., 2003, Metodologi penelitian, Jakarta; Ghalia Indonesia

Mulyadi, Johny Setyawan, 2001, Sistem perencanaan dan pengendalian manajemen, Universitas Gadjah Mada.

Pariaman Sinaga. 2004. Balanced scorecard sebagai pengukuran kinerja koperasi dan UKM, Infokop Nomor 25 Tahun XX.

Riyanto L. S., Bambang, 2001, The effect attitude, strategy and decentralization on the effectiveness of budget participation, Jurnal Riset Akuntansi Indonesia, Volume 2, No. 2 Edisi Juli.

Indar Khaerunnisa: Measuring Job Performance of The Economic Creative Business upon Women Enterpreneurs Base (Case Study at Online Bunda Community Bogor Branch Using 